\title{
INTERNAL POWER RELATIONSHIP AND ORGANIZATIONAL CHANGE
}

\author{
F. Gülruh GÜRB $\ddot{U} Z$ \\ Marmara Üniversitesi İ.̇..B.F. İngilizce İşletme Bölümü, Yardımcı Doçent Dr.
}

\begin{abstract}
Özet:İşletmelerde değişim kaçınllmaz bir olgudur. Değişimin sağlkkl bir şekilde gerçekleşmesi ve başartl olabilmesi için attlacak adtmlar arastnda en önemli olant sirket içi gü̧ dengelerinin iyi ayarlanmastdrr. Bu konuda en önemli görev yöneticilere düşer.Lyi yönetici gücü tamamiyla kendi elinde tutan kişi değil, tam tersine kendisine bağll isgö̈renleri de bilgilendiren, yetkilendiren, dolayısiyla güçlendiren kişidir. Güçlendirilmiş işgörenlerin işyerlerine olan bağhlhklarl ve iş tatmini artar, dolaytstyla daha basartl ve verimli olmalart doğaldır. Güçlendirme, ayn zamanda işgörenlerin değişime karşı duyacağı tepkiyi de azaltıcı bazen de yok edici bir rol oynar; çünkï isggörenler şirketle ilgili kararlardan haberdar edildiklerinden dolayı, bu kararları onlart nast etkileyeceğ $i$ konusunda boşluğa düşmezler.
\end{abstract}

\section{INTRODUCTION}

The gap between designing a new organization on paper and bringing it into reality is the domain of organizational development and change. Organizational change is the adoption of a new idea or behavior by an organization [1], whereas organizational development is the application of behavioral science knowledge to improve an organization's health and effectiveness through its ability to cope with environmental changes, improve internal relationships and increase problem solving capabilities [1]. It often happens that management's awareness for a new organization design emerges only after the start of an intensive change process. And even if it were possible for an omniscient manager to develop a master blueprint before introducing organization change, it is doubtful that other employees would readily accept the new design or have the required skills for making the design work. For these reasons, managers need to be as skillful at handling the question of how to introduce change and what needs to be changed [2].

A variety of goals are present for an organizational change and development. On the surface, the most common goals can be categorized under labels such as higher performance, acceptance of new techniques, greater motivation more innovation, increased cooperation, reduced turnover, conflict management, fitting different cultures into one after mergers and acquisitions and so forth. Organizational changes are frequently directed at one or more of these general goals. In fact changes in an organization's level of adaptation to its environment, and changes in the internal behavioral patterns of employees are two main objectives. Organizations are continuously trying to adapt themselves to their external environment. Because the management of an organization cannot completely control its environment, they have to introduce internal organizational changes which allow them to cope more effectively with new challenges presented from outside by increased competition, advances in technology, new government legislation, and pressing social demands.

The second objective of organizational change is to achieve modifications in behavior patterns. This is mainly because of an organization's level of adaptation to the external environment can not be improved unless many of its employees behave differently in relationship to each other and to their jobs. Organizations do not operate through computers but through people who make decisions, and every organization has its unique patterns of decision making behavior. These patterns stem from both formal and informal ground rules which specify how a good manager or employee should behave in relating to others and making decisions.. Thus, any organizational change, whether it is introduced through a new structural design or a training program, is basically trying to get employees to adopt new patterns of behavior and ground rules for relating to each other and to their jobs. For organization-wide effects to be felt, these new behavior patterns must emerge not only within superior-subordinate relations, but between and within work groups, and extend out to include larger subsystems(departments and divisions) of the total organization.

In any organization, actualizing the organizational change is not an easy task because it concerns a number of steps such as; identifying the destabilizing forces, choosing what to change, selecting the appropriate methods to use, designing the most effective change strategies, implementing them with the correct tactics. It is more easy to implement the other steps if destabilizing forces in the organization are understood and defined. In 
any organization destabilizing forces are the internal power relationships [3].

\section{INTERNAL POWER RELATIONSHIPS \& ITS EFFECTS ON ORGANIZATIONAL CHANGE}

The main issue of internal power is who is making the decisions and on what basis?". Unilateral decisions tend to be based on the positional authority of top people, while delegated decisions depend more on the knowledge and skill of lower level managers. Power sharing in the organizations can be seen in three for [2]:

\section{A. Unilateral Power}

a) The Decree Approach: A one-way announcement originating with a person with high formal authority and passed on to those in lower positions.

b) The Replacement Approach: Individuals in one or more key organizational positions are replaced by other individuals. The basic assumption is that organizational change is a function of key man's ability.

c) The Structural Approach : Instead of decreeing or injecting new blood into work relationships, management try to change the required relationships of subordinates. By changing the structure of organizational relationships, organizational behavior is also affected.

\section{B. Shared Power}

1. The Group Decision Approach: There is participation by group members in selecting from several alternative solutions specified in advance by superiors. This approach involves neither problem identification nor problem solving, but emphasizes the obtaining of group agreement to a particular course of action.

2. The Group Problem Solving Approach : Problems should be identified and solved through group discussions. Here, the group has wide latitude, not only over choosing the problems to be discussed, but then in developing solutions to these problems.

\section{Delegated Power}

1. The Data Discussion Approach: Organizational members are encouraged to develop their own analysis of the data, presented in the form of case materials, survey findings, or data reports.

2. The Sensitivity Training Approach: Managers are trained in small discussion groups to be more sensitive to underlying processes of individual and group behavior.
Changes in work patterns and relationships are the result of changes in interpersonal relationships. Sensitivity approaches focus upon interpersonal relationships first, then hope for, improvements in work performance.

Good managers, ones who get the best out of their subordinates and who thereby produce positive results for their organizations, are the keys to an organization's success. It is not surprising, then, that much research and thought has gone into trying to define just what motivates a good manager. In reality power motivates managers. Almost by definition, a good manager is one who, among. other things, helps subordinates feel strong and responsible, who rewards them properly for good. performance, and who sees that things are organized in such a way that subordinates feel they know what they should be doing. Above all, managers should foster among subordinates a strong sense of team spirit, of pride in working as part of a particular team. If a manager creates and encourages this spirit, his subordinates certainly should perform better. Here, the term "power motivation" does not refer to dictatorial behavior, but to a desire to have an impact, to be strong and influential. Above all, the good manager's power motivation is not oriented toward personal aggrandizement but toward the institution he or she serves. Moreover, the managers who are motivated by a need for personal power are somewhat more effective. They are able to create a greater sense of responsibility in their divisions, and a greater team spirit. However, managers motivated by personal power are not disciplined enough to be good institution builders, and often their subordinates are loyal to them as individuals rather than to the institution they both serve. When a personal-power manager leaves, disorganization often follows. His subordinates' strong group spirit, which the manager has personally inspired, deflates. The subordinates don't know what to do for themselves. Of the managerial types, the "Institutional" manager is the most successful in creating an effective work climate. This kind of manager creates high morale because he produces the greatest sense of organizational clarity and team spirit. If such a manager leaves, he or she can be more readily replaced by another manager, because the employees have been encouraged to be loyal to the institution rather than to a particular person [4].

\section{POWER DEPENDENCE and EFFECTIVE MANAGEMENT}

One of the distinguishing characteristics of a typical manager is how dependent he or she is in activities of a variety of other people to perform his or her job effectively: Unlike doctors and mathematicians, whose performance is more directly dependent on their own talents and efforts, a manager can be dependent in varying 
degrees on superiors, subordinates, peers in other parts of the organization, the subordinates of peers, outside suppliers, customers, competitors, unions, regulating agencies, and many others [5]. These dependency relationships are an inherent part of managerial jobs because of two organizational facts of life; division of labor and limited resources. Because the work is divided into specialized divisions, departments, and jobs, managers are made directly or indirectly dependent on many others for information, staff services, and cooperation in general. Because of their organization's limited resources, managers are also dependent on their external environment for support. Without some minimal cooperation from suppliers, competitors, unions, regulatory agencies, and customers, managers cannot help their organizations survive and achieve their objectives. Dealing with these dependencies and the manager's subsequent vulnerability is an important and difficult part of a manager's job because, while it is theoretically possible that all of these people and organizations would automatically act in just the manner that a manager wants and needs, such is never the case in reality. All the people on whom a manager is dependent have limited time, energy, and talent. Some people may be uncooperative because they are too busy elsewhere, and some because they are not really capable of helping, others may well have goals, values, and beliefs that are quite different and in conflict with the manager's and may therefore have no whatsoever to help or cooperate. This is obviously true of a competing company and sometimes a union, but it can also apply to a boss who is feeling threatened by a manager's career progress or to a peer whose objectives clash with the manager's.

Indeed, managers often find themselves dependent on many people whom they don't directly control and who are not cooperating. This is the key to one of the biggest frustrations that managers feel in their jobs. But in fact to be able to plan, organize, budget, staff, control and evaluate, managers need some control over the many people on whom they are dependent. Trying to control others solely by directing them and on the basis of the power associated with one's position simply will not work. First, because managers are always dependent on some people over whom they have no formal authority, and second, because no one in modern organizations will passively accept and completely obey a constant stream of orders from someone just because he or she is the boss [6]. Trying to influence others by means of persuasion alone does not work either. Although it is a powerful and important method of influence, persuasion has some serious drawbacks too. To make it work requires time, skill, and information on the part of the persuader, and persuasion can fail simply because the other person chooses not to listen or does not listen carefully.
Good managers can use the power they develop in their relationships, along with persuasion. They use their power to influence others directly, face to face, and in more indirect ways depending on situation. If the power exists and the manager understands the nature and strength of it, he can influence the other person with nothing more than a brief request or command. Successful managers cope with their dependence on others by being sensitive to it, by eliminating or avoiding unnecessary dependence, and by establishing power over those others. Good managers then use that power to help them plan, organize, staff, budget, evaluate, and so on. In other words, it is primarily because of the dependence inherent in managerial jobs that the dynamics of power necessarily form an important part of a manager's processes.

\section{EMPLOYEE EMPOWERMENT}

Effective organizations must continually adapt to their changing environments, and current shifts in organizational environments of the past. The forces of global competition, expanded technology, shifting worker demographics, and societal value changes are pressuring organizations to adopt new structures and behaviors. Many of these structures and behaviors focus on increasing the effectiveness of human resources through more worker participation and less managerial control. While some employees may resist increased participation, greater leveis of worker involvement allow individuals and groups to have wider repertoires of activity, thereby helping organizations to better adapt to their dynamic, multidimensional environments. A frequently cited outcome of increased worker involvement is employee empowerment. Empowerment is the process by which a manager enables people in a work team to produce results by providing the necessary environment [7]. Empowerment gives employees the ability, authority, and responsibility to make decisions and thereby react quickly to problems. Empowered employees are relatively autonomous, and have the freedom to adjust to shifting demands by leading themselves and working cooperatively.

The word empowerment has had strong positive connotations for practitioners. It has emerged as a popular construct as organizations have had advanced into the information age. Organizations are structured as clusters and networks; they rely on decentralized structures rich in lateral communication processes, distributed information systems to support decision making, and self-managing workers willing to take risks and exercise initiative. Practitioners have borrowed the term largely from sociologists who viewed empowerment as unleashing tremendous energy and determination for social action at the grass roots level. The popular idea seemed to refer to 
this energy and motivational force, and it assumed the delegation of authority to lower levels would unleash this same energy [8].

Delegation and other empowerment-related concepts are divided into three sets of variables. The first are; conditions influencing the workers, including delegated authority, but also visionary leadership, and access to information and psychological support. The second are; psychological states in the workers, for example, a sense of self-efficacy, choice, and meaningfulness. The third are; desired outcomes, including self-management, quality of work life, and work quality [9].

Empowerment obviously makes a difference in organizations. It beneficial for an organization in two ways; through increased job satisfaction and retention and through increased self-management. Since empowerment is defined in terms of intrinsic task rewards, the link to job satisfaction and retention is relatively straightforward. It appears to be the link to self-management and it is likely performance benefits that needs more work. Empowered individuals believe in and care about what they do; their activity is aligned with their value system. They have passion, investment of energy in activity. Those who are empowered have spiritual energy. Empowered individuals feel a sense of personal significance from their involvement. They have a sense of self-identity and personal integrity through their involvement; empowered individuals have a personal connectedness to the activity at hand.

Empowerment has strong relations with competence as well. In addition to what they do, empowered people believe in their abilities and capacities. Empowered individuals have a sense of self-effectiveness or personal competence. Not only do they believe that they have requisite skills and abilities, but they also have the confidence that they can perform adequately. Empowered individuals believe in their capacity to learn and grow to meet new challenges. They have a sense of personal mastery and competence. Empowered individuals see themselves as making a difference, that is producing the intended effect in one's task environment. They don't believe that barriers in the external environment control the outcomes of their actions; they believe they can effect desired change, manipulate, and have some control in the larger environment. Empowered individuals both participate and at least partially dominate strategic conversations in organizations. Empowered individuals don't experience a sense of learned helplessness. They don't believe that the outcomes of their actions are predetermined, inevitable or dictated externally. Organizations capable of benefiting from the outcomes of empowerment can enjoy dramatic improvements as they increase the power of workers. The transition, however will not be easy, it requires a systems perspective that focuses on altering the behavior of many different people. This means that significant efforts will be needed to try to better understand the relevant motivations and behaviors of both employees and supervisors. Until supervisors empower employees with greater knowledge and responsibility, meaningful changes in actual behavior are unlikely. Paradoxically, supervisors believe that the employees have the skill and ability necessary to lead themselves. This suggests that organizational development efforts designed to influence supervisors are a key part of any transition toward greater empowerment [9].

\section{OUTCOMES OF EMPOWERED TEAMS}

It is crucial to answer the question of what happens when an employee becomes empowered? The answer is [7]: Job satisfaction and productivity of the employee increases, employee becomes proactive and committed to his organization, resistance to change decreases and quality and customer satisfaction increases.

Employees who work in autonomous teams express higher job satisfaction ratings than employees working in traditional settings in the same companies. While team satisfaction may not be a direct result of summing individual job satisfaction ratings, it is not unreasonable to assume that collective team satisfaction will be related to the satisfaction of individual team members in an additive fashion. The more an employee actively participates in his or her job and funds his or her performance central to selfesteem, the more likely the person will feel satisfied. Active participation and meaningfulness are, in turn, affected by the scope of activities done, which should be large on an empowered work team. Thus, the higher the level of team empowerment, the higher will be the team's level of job satisfaction.

Empowerment has been found to be positively related to individual performance and self-directed work team performance. A sense of controllability within an organization enhances the performance of managers. Consistent with participative decision making, employees who have a more complete knowledge of their job often make better job-related decisions. Also, the external conditions imposed on a team can hamper its performance. An empowered team should have fewer external constraints, and thus be more effective. Thus, the higher the level of team empowerment, the higher will be the team's productivity.

A person is more likely to be committed to the organization if he or she feels important to the 
organization, a feeling likely to be linked to the knowledge that a team has consequences for the rest of the organization. And, organizational commitment can be built through the use of empowered work teans. Thus, the higher the level of team empowerment, the higher will be the team's level of organization and team commitment.

By their very nature, empowered work teams are designed to be proactive. Empowerment represents a proactive orientation toward the job, management, and the organization. Empowered teams have the responsibility for all phases of work. Increased control over future events should lead to proactive behavior.

In general, employees will show resistance to any change in the company if they think that the proposed change will lead to loss of power, prestige, pay or company benefits, if they don't understand the intended purpose of the change and if they worry about whether they will be able to meet the demands of the change taking place in the organization [10]. Facets of empowered work teams may help limit employee resistance to change, particularly to working in teams. Empowered teams have access to key information in the organization including strategic information that provides a rationale for management initiatives. Greater decision making authority should allow for more input into management initiatives, and empowered work team potency should act to increase confidence in the initiative. Finally, empowered work teams create meaningfulness for team members when their tasks are consistent with their beliefs, attitudes and values.

Some organizations implement work teams within an overall total quality management process. Empowered teams handle customer complaints directly and are often responsible for the quality of their products or services. One of the basic tenets of TQM is that employees who respond to customer issues directly will provide higher quality customer service than employees who are removed from customer contact. In many instances, empowered teams have the discretion to deal directly with customers. Thus, the higher the level of team empowerment, the higher will be the team's level of quality/customer satisfaction.

\section{CONCLUSION}

In conclusion, there are many reasons for the organizational change and development process such as higher performance, new techniques, innovation, reduced turnover, changing roles and power relationships in organizations and so on. There is no doubt that the way the power is used within the company, the level of dependence among people and employee empowerment all have crucial effects on organizations. As the use of power moves from unilateral to shared and then delegated, there occurs a high need for improving skills and knowledge of the organization members in order to match their new responsibilities and power relationships with this new emerging organization power structure. The dependence level of managers on subordinates or other people in the organization may be influential too. This fact may force managers to review their relationships, to exercise their power to influence others along with persuasion in order to get jobs done effectively. Successful managers should eliminate and avoid unnecessary dependence within the organization.

More worker participation and less managerial control trends will also lead to a change in organizations as we are more and more surrounded by dynamic and multidimensional environments. The organizations will rely on decentralized structures, distributed information systems and workers will be willing to take more risks and initiative. From psychological point of view, the workers will have strong sense of self-efficacy, choice and meaningfulness within the organization. 


\section{REFERENCES}

[1] DAFT, Richard L., Management, $5^{\text {th }}$ Edition, Dryden Press, 2000, ss.363, 383.

[2] DALTON, Gene W.; LAWRENCE, Paul R., Organizational Change \& Development, The Dorsey Press, 1970, ss.3, 12.

[3] CONNOR, Patrick E; LAKE, Linda K., Managing Organizational Change, Praeger Publishers, 1988, s.130.

[4] -.---.-, "The President \& Fellows of the College", Harvard Business Review on Human Relations, Harper and Row Publishers, 1979, s.35.

[5] GUSTAVSEN, Bjorn; HOFINAIER, Bernd; PHILIPS, Marianne Ekman; WIKMAN, Anders, Concept Driven Development \& The Organization Of The Process of Change, John Benjamin's Publishing Co., 1996, s.68.

[6] KANTER, Rosabeth Moss; STEN, Barry A.; JICK, Todd D., The Challenge of Organizational Change, Free Press, 1994, s.121.

[7] MINK, Oscar G.; OWEN, Keith Q.; MINK, Barbara P., Developing High Performance People, Addison Wesley, 1993, ss.39-42.

[8] PASMORE, William A.; WOODMAN, Richard W., Research In Organizational Change \& Development, JM Press Ltd., 1997, ss.40, 148.

[9] BURKE, W. Warner, Organizational Development A Process of Learning and Change, Addison-Wesley Publishing Co., 1994, Chapter 4.

[10] JONES, Gareth R.; GEORGE, Jennifer M.; HILL, Charles W.L., Contemporary Management, $2^{\text {nd }}$ Edition, McGraw-Hill International Edition, 2000, ss.595- 598. 